\title{
EFEKTIVITAS LEG EXERCISE DAN KOMBINASI DEEP BREATHING TERHADAP MEAN ARTERIAL PRESSURE (MAP) PADA PASIEN POST OPERASI
}

\author{
Vita Dwi Futmasari ${ }^{1}$, Rodhi Hartono ${ }^{2}$, Mardiyono ${ }^{2}$ \\ ${ }^{1}$ Mahasiswa Program Studi D-IV Keperawatan, Jurusan Keperawatan, Poltekkes Kemenkes Semarang \\ ${ }^{2}$ Dosen Jurusan Keperawatan, Poltekkes Kemenkes Semarang \\ Korespondensi: vitafutmasari25@gmail.com
}

\begin{abstract}
Background: Patient post-operative had experienced a critical period after surgery and anesthesia, the body's physiological interference occurred among hypotension. The impact was hypoperfusion for the infarction brain tissue and death. Therefore, it was necessary interventions trigger cardiovascular system used the Leg Exercises and Deep Breathing exercises.

Purpose: To examine the effectiveness combination of Leg Exercises and Deep Breathing for mean arterial pressure.

Methods : This study used Quasi Experiment randomized pre-test post-test control group design, These samples were 51 respondents in Roemani Semarang Hospital on January $2^{\text {nd }}$ to February $24^{\text {th }} 2019$. The technique collected at lottery simple random sampling and the tests used Kruskal Wallis post hoc Mann Whitney.

Results : The results showed the highest average to increase MAP for the difference prepost and the post was the combination group with $p=0,000$ on Kruskal Wallis test. The post hoc Mann Whitney test showed average to increase MAP in the control group and the Leg Exercise is same with the $p$ value $>0,05$ and the combination higher than Leg Exercise with the $\mathrm{p}$ value $<0,05$. It's meant that the combination most effectively to increase MAP and had clinical significant with $\mathrm{p}=0,000$.

Conclusion : This study presented the combination of Leg Exercise and Deep Breathing most effectively to prevent hypotension in patients post-surgery with spinal anesthesia in Roemani Semarang Hospital.
\end{abstract}

Keywords : Deep Breathing, Hypotension, Leg Exercise

\section{LATAR BELAKANG}

Anestesia adalah upaya menghilangkan nyeri pada saat dilakukan pembedahan. Proses menghilangkan nyeri tanpa menghilangkan kesadaran disebut anestesia lokal atau regional. Anestesia spinal ialah teknik anestesia regional dengan blokade ke ruang subarachnoid (Sjamsuhidajat, 2010).

Menurut WHO (2013) dalam Ningrum dkk. (2017) jumlah pasien di dunia dengan tindakan operasi pada tahun 2011 terdapat 140 juta jiwa sedangkan pada tahun 2012 data mengalami peningkatan sebesar 148 juta jiwa. Analisis data dari 13.654 pasien menunjukkan data dalam tiga bulan terakhir terjadi pembedahan dengan anestesi spinal 
di dunia sejumlah 3,95\%(539/13654) dan 12,2\% (766/6274) dalam 4 tahun terakhir (Heindel P dkk., 2017). Pada tahun 2004-2015, di Asia terdapat 45.831 operasi dengan anestesi spinal di antaranya operasi tulang belakang (Kobayashi dkk., 2018).

Pada tahun 2012, kejadian operasi di Indonesia mencapai 1,2 juta jiwa dan diperkirakan 9,8 \% dilakukan operasi dengan anestesi spinal (Ningrum dkk., 2017; Sihombing dkk., 2010). Pada tahun 2013, data menunjukkan sejumlah 3,5\% operasi dengan anestesi umum, 3,8 \% anestesi epidural dan 0,3\%, anestesi spinal di RSUP Dr. Kariadi Semarang (Riyanto dkk., 2013).

Pasca anastesia merupakan periode kritis dimulai setelah pembedahan dan anesthesia, terjadi gangguan fisiologis tubuh yang berefek pada berbagai sistem organ pasien. Efek yang terjadi setelah pembedahan dengan anestesi spinal di antaranya hipotensi, mual muntah, retensi urin, sakit kepala (The Royal College of Anaesthetists, 2014). Insiden hipotensi di dunia pasca operasi dengan anestesi spinal sebesar 80\% (Tanambel dkk., 2017).

Efek lainnya yang mempengaruhi perubahan nilai tekanan darah sistolik, frekuensi nadi, cardiac output, stroke volume, peristaltik usus, saturasi oksigen Menurut penelitian, insiden penurunan MAP pada pasien post operasi dengan persentase penurunan dari MAP awal ke MAP sesudah anestesi spinal bervariasi, yaitu: penurunan sebesar 2\% (1 pasien); 3,85\% (1 pasien); 8,24\% (1 pasien); $12 \%$ (1 pasien); $11,52 \%$ (1 pasien); $10 \%$ (4 pasien); $0,38 \%$ (1 pasien); $7,35 \%$ ( 2 pasien); $8,82 \%$ (1 pasien); $9,68 \%$ (1 pasien); dan $10,94 \%$ (1 pasien) (Tanambel dkk., 2017).

Hipotensi merupakan salah satu dampak anestesi yang cukup serius. Hal ini disebabkan adanya hipovolemia (penurunan preload), penurunan afterload (kontraksi otot jantung/tekanan memompa ventrikel), kegagalan dalam memompa jantung karena efek anestesi belum hilang (depresan otot jantung). Jika hipotensi tidak tertangani, terjadi hipoperfusi dari organ vital yang menyebabkan iskemik dan infark jaringan pada otak (hipoksia). Oleh karena itu, intervensi selama dan setelah 24 jam pertama sangat berpengaruh terhadap salah satu sistem yaitu sistem kardiovascular. Intervensi yang mempengaruhi sirkulasi darah diantaranya Leg Exercise dan Deep Breathing. Kedua intervensi ini sejalan dengan penelitian, mengenai Leg Exercise pada pasien post operasi laparotomi dengan anestesi umum, rata-rata MAP berubah menjadi 90.18. Ada pengaruh Leg Exercise terhadap perubahan tekanan darah pada pasien post operasi laparotomi dengan anestesi umum (Sukawati dkk., 2017).

Studi pendahuluan yang dilakukan di ruang IBS RS Roemani Semarang didapatkan total kasus pembedahan sebanyak 519 operasi. Tindakan operasi dengan anestesi umum sebanyak 260 (50\%), anestesi spinal sebanyak 232 (44,7\%), anestesi lokal sebanyak 27 $(5,3 \%)$ dan tidak ada operasi yang menggunakan anestesi epidural. Pembedahan dengan anestesi spinal menduduki peringkat kedua dari semua anestesi yang digunakan di rumah sakit tersebut. Rata-rata kondisi pasien setelah operasi dengan anestesi spinal didapatkan 90\% mengalami hipotensi. Tindakan untuk mengatasi hal tersebut di antaranya resusitasi cairan kristaloid, kolaborasi pemberian efedrin dan head up $30^{\circ}$ selama 24 jam. Setelah 
24 jam pertama dilakukan mobilisasi sesuai advice dokter (Rekam Medis RS Roemani Semarang, 2018).

Berdasarkan fenomena di atas, maka peneliti tertarik untuk melakukan penelitian dengan judul "Efektivitas Leg Exercise dan Kombinasi Deep Breathing Terhadap Mean Arterial Pressure Pada Pasien Post Operasi Anestesi Spinal di RS Roemani Semarang".

\section{TUJUAN}

Tujuan umum penelitian ini adalah untuk menganalisis efektivitas kombinasi Leg Exercise dan Deep Breathing terhadap Mean Arterial Pressure pada pasien post operasi anestesi spinal di RS Roemani Semarang.

\section{METODE}

Penelitian ini menggunakan desain penelitian Quasy Experiment. Rancangan menggunakan randomised pre test post test with control group. Peneliti melakukan penelitian dengan menggunakan dua kelompok sampel perlakuan meliputi kelompok sampel dengan intervensi Leg Exercise dan kelompok sampel dengan intervensi kombinasi Deep Breathing. Terdapat satu kelompok kontrol yaitu kelompok Deep Breathing.

Penelitian dilakukan pada tanggal 2 Januari - 24 Februari 2019 di RS Roemani Semarang dengan jumlah responden sebanyak 51 orang. Terdapat 3 kelompok yang masing-masing kelompok memiliki 17 orang. Kriteria inklusi sebagai berikut : berusia $\geq 18$ tahun , pemberian cairan RL setelah dari recovery room, anestesi spinal dengan Bupivakain $\mathrm{HCl}$, sign out mulai pukul 07.30 - 13.00 WIB. Kriteria eksklusi sebagai berikut : operasi sectio caesarea dan hernioplasty dan pasien yang mengalami kegawatan saat intervensi.

Instrumen yang digunakan yaitu inform consent, identitas responden, lembar observasi, lembar standar operasional prosedur, spigmomanometer pegas yang telah terkalibrasi. Lalu, memasukkan hasil pengukuran tekanan darah ke rumus MAP dengan kategori rendah $<80 \mathrm{mmhg}$, normal 80-105mmhg dan tinggi $>105 \mathrm{mmhg}$.

Analisis data yang digunakan adalah uji Wilcoxon untuk perbedaan masing-masing kelompok. Uji Kruskal Wallis Post Hoc Mann Whitney digunakan untuk perbedaan ketiga kelompok dan menentukan kelompok yang paling efektif. 
HASIL

Karakteristik Responden

Tabel 1 Karakteristik Responden berdasarkan jenis kelamin, usia,tindakan pembedahan, pemberian efedrin $(n=51)$

\begin{tabular}{|c|c|c|c|c|}
\hline Karakteristik & Leg Exercise & Kontrol & Kombinasi & $P$ value \\
\hline \multicolumn{5}{|l|}{$\operatorname{Umur}[\mathrm{n}(\%)]$} \\
\hline $18-40$ & $2(3,93)$ & & $2(3,93)$ & \multirow{3}{*}{$0,532 *$} \\
\hline $41-59$ & $11(21,56)$ & $9(17,64)$ & $14(27,46)$ & \\
\hline$>59$ & $4(7,83)$ & $8(15,68)$ & $1(1,97)$ & \\
\hline \multicolumn{5}{|l|}{ Jenis Kelamin $[\mathrm{n}(\%)]$} \\
\hline Laki-laki & $14(27,46)$ & $15(29,42)$ & $13(25,5)$ & \multirow{2}{*}{$0,208 *$} \\
\hline Perempuan & $3(5,86)$ & $2(3,93)$ & $4(7,83)$ & \\
\hline \multicolumn{5}{|l|}{$\begin{array}{l}\text { Tindakan Pembedahan } \\
{[\mathrm{n}(\%)]}\end{array}$} \\
\hline Litotripsi & & $3(5,86)$ & & \\
\hline Cystoscopy Elich & & $1(1,97)$ & & \\
\hline Nefrektomi & & $1(1,97)$ & & \\
\hline Hemoroidektomi & $1(1,97)$ & $2(3,93)$ & $2(3,93)$ & \\
\hline Hernioraphy & $4(7,83)$ & $3(5,86)$ & $2(3,93)$ & \\
\hline TURP & $3(5,86)$ & $2(3,93)$ & $4(7,83)$ & \\
\hline TURBT & & & $1(1,97)$ & $0,407 *$ \\
\hline URS & $6(11,75)$ & $4(7,83)$ & $5(9,8)$ & \\
\hline Prostatektomi & $2(3,93)$ & $1(1,97)$ & & \\
\hline Neoimplantasi & $1(1,97)$ & & & \\
\hline Nefrolitotomi & & & $1(1,97)$ & \\
\hline Fissurektomi & & & $1(1,97)$ & \\
\hline Palomo varikokel & & & $1(1,97)$ & \\
\hline Pemberian & & & & \\
\hline Efedrin $[\mathrm{n}(\%)]$ & & & & $0,550^{*}$ \\
\hline $\mathrm{Ya}$ & $3(5,85)$ & $2(3,93)$ & $2(3,93)$ & \\
\hline Tidak & $14(27,45)$ & $15(29,42)$ & $15(29,42)$ & \\
\hline
\end{tabular}

* Lavene test

Berdasarkan tabel 1 didapatkan frekuensi umur terbanyak di rentang usia 41-59 tahun, jenis kelamin terbanyak adalah laki-laki, tindakan pembedahan terbanyak adalah URS, pemberian efedrin hanya pada 7 orang dari total 51 orang. 


\section{Gambaran Uji Homogenitas}

Tabel 2 Uji Homogenitas MAP Pre $(n=17)$

\begin{tabular}{ccc}
\hline Kelompok & Mean \pm SD & P value \\
\hline Leg Exercise & $80,588 \pm 5,0229$ & \\
Kontrol & $80,394 \pm 4,0622$ & 0,811 \\
Kombinasi & $80,394 \pm 5,2574$ & \\
\hline
\end{tabular}

Berdasarkan tabel 2 didapatkan MAP pre pada uji homogenitas menunjukkan $\mathrm{p}$ value $>0,05$ sehingga ditarik simpulan data bersifat sama atau homogen.

\section{Gambaran MAP Sebelum dan Sesudah Intervensi}

Tabel 3 Perbedaan MAP pada masing-masing kelompok antara sebelum dan sesudah intervensi $(n=17)$

\begin{tabular}{|c|c|c|c|c|c|}
\hline \multirow{2}{*}{ Kelompok } & Pre & Post & \multirow{2}{*}{$\begin{array}{c}\text { Mean } \\
\text { rank }\end{array}$} & \multirow{2}{*}{$\mathrm{z}$} & \multirow{2}{*}{$P$ value } \\
\hline & \multicolumn{2}{|c|}{ Median (Min-Max) } & & & \\
\hline Leg Exercise & $80(70-93,3)$ & $86,7(80-100)$ & 5,5 & $-2,823$ & 0,005 \\
\hline Kontrol & $80(70-90)$ & $80(80-96,7)$ & 5,5 & $-2,848$ & 0,004 \\
\hline Kombinasi & $80(70-90)$ & $100(86,7-103,3)$ & 9 & $-3,638$ & 0,000 \\
\hline
\end{tabular}

Berdasarkan tabel 3 didapatkan data rata-rata peningkatan MAP tertinggi pada kelompok Kombinasi yaitu 9 mmhg. Hasil uji wilcoxon menunjukkan $\mathrm{P}$ value kelompok Leg Exercise yaitu 0,005 sehingga ditarik simpulan ada perbedaan bermakna sebelum dan sesudah intervensi. P value kelompok kontrol yaitu 0,004 sehingga ditarik simpulan ada perbedaan bermakna sebelum dan sesudah intervensi. P value kelompok kombinasi yaitu 0,000 sehingga ditarik simpulan ada perbedaan bermakna sebelum dan sesudah intervensi.

Tabel 4 Perbedaan MAP antar kelompok $(n=51)$

\begin{tabular}{lrrr}
\hline \multicolumn{1}{c}{ Kelompok } & $\begin{array}{c}\text { Mean } \\
\text { rank }\end{array}$ & $\mathrm{U}$ & P value \\
\hline MAP Post & & & \\
Leg Exercise & 19,68 & 107,5 & 0,187 \\
Kontrol & 15,32 & & \\
Leg Exercise & 11,03 & 34,5 & 0,000 \\
Kombinasi & 23,97 & & \\
Kontrol & 10,38 & 23,5 & 0,000 \\
$\quad$ Kombinasi & 24,62 & & \\
MAP Selisih & & & \\
Leg Exercise & 18,50 & 127,5 & 0,541 \\
Kontrol & 16,50 & &
\end{tabular}




\section{Tabel Lanjutan}

\begin{tabular}{llll}
\hline Kelompok & $\begin{array}{l}\text { Mean } \\
\text { rank }\end{array}$ & $\mathrm{U}$ & $\mathrm{P}$ value \\
\hline Leg Exercise & 11,74 & 46,5 & 0,001 \\
Kombinasi & 23,26 & & \\
Kontrol & 10,59 & 27 & 0,000 \\
Kombinasi & 24,41 & & \\
\hline
\end{tabular}

Berdasarkan tabel 4 didapat ada perbedaan signifikan MAP post dan selisih prepost pada kelompok Leg Exercise dengan Kombinasi dan kelompok Kontrol dengan Kombinasi. Pada uji Kruskal Wallis post hoc Mann Whitney menunjukkan peningkatan rata-rata MAP pada kelompok Kontrol dan Leg Exercise bernilai sama ( $>0,05)$. Namun pada kelompok Kombinasi lebih tinggi dari Leg Exercise ( $<<0,05)$. Hal ini menandakan adanya peningkatan rata-rata MAP signifikan tertinggi pada kelompok kombinasi sehingga ditarik simpulan bahwa Kombinasi lebih efektif atau terdapat klinikal signifikan terhadap peningkatan MAP. Hasil didapatkan rata-rata awal MAP 80,39 mmhg menjadi rata-rata akhir perlakuan 97,24 mmhg yang menunjukkan MAP dalam rentang normal, dan mengalami peningkatan MAP tertinggi sebesar 16,85 mmhg.

\section{PEMBAHASAN}

Hasil penelitian ini menunjukkan peningkatan rata-rata MAP sebelum dan sesudah pada masing-masing kelompok Leg Exercise sebesar 5,5, kelompok Deep Breathing sebesar 5,5 dan kelompok Kombinasi Leg Exercise dan Deep Breathing sebesar 9 dengan masingmasing $\mathrm{p}$ value $<0,05$. Ada perbedaan MAP sebelum dan sesudah kombinasi Leg Exercise dan Deep breathing dengan $\mathrm{p}=0,000$. Hal ini dapat terjadi karena gerakan pada kaki dapat memicu sirkulasi darah terdorong menuju jantung dan meningkatkan kontraksi memompa. Kemudian, pada saat ekspirasi terjadi peningkatan sirkulasi darah pada daerah yang kekurangan oksigen sehingga memicu terjadinya pelebaran pada pembuluh darah kaki.

Menurut penelitian Kwon dkk. (2013) yang mengatakan bahwa kombinasi efektif terhadap kecepatan aliran darah vena femoralis yang diukur dengan Dopplex Advanced Doppler. Kecepatan aliran darah pada kelompok Deep Breathing $(D B) 15,5(3,9) \mathrm{cm} / \mathrm{sec}$, Ankle Exercise With Quiet Breathing (AQB) 20,7 (6,6) cm/sec, Ankle Exercise Combined With Deep Breathing $(A D B) 26,5(9,4) \mathrm{cm} / \mathrm{sec}$. Hal ini menunjukkan bahwa nilai kelompok kombinasi lebih tinggi dari kelompok deep breathing maupun ankle exercise saja.

Kombinasi efektif dalam mencegah vena statis atau insufisiensi vena pada kaki dan membantu peningkatan tekanan darah agar tidak terjadi hipotensi. Hal ini karena kecepatan aliran darah vena meningkat $102,8 \%$ selama dilakukan latihan pada tungkai kaki dengan posisi kepala hampir berbaring. Gerakan fleksi rotasi pada kaki menghasilkan kecepatan tertinggi pada aliran darah dengan peningkatan kecepatan aliran darah vena $38 \%$ dan $58 \%$ peningkatan aliran puncak atau volume darah yang masuk ke jantung bertambah saat kaki ditinggikan posisi $30^{\circ}$. Kemudian, latihan kaki dilanjut dengan Deep Breathing dimana kecepatan aliran darah vena cava inferior meningkat saat 
ekspirasi perlahan. Pada saat ekspirasi, maka terjadi peningkatkan tekanan intratorakal negatif yang menyebabkan peningkatan sirkulasi darah menuju ke dada. Bersamaan dengan itu, otot jantung akan meregang untuk kontraksi.

Ada perbedaan MAP sebelum dan sesudah Leg Exercise dengan p=0,005. Hal ini dapat terjadi karena menegangnya otot kaki hingga menekan vena untuk mendorong darah menuju jantung. Penelitian ini sejalan dengan penelitian berjudul pengaruh Leg Exercise terhadap MAP, pada kelompok Leg Exercise post operasi laparotomi dengan anestesi umum, rata-rata MAP post 90,18 mmhg dari pre 80,16 mmhg dengan $\mathrm{p}=0,044$. Pada penelitian ini, Leg Exercise membantu dalam peningkatan kontraksi otot lutut sehingga terjadi peningkatan tekanan vena yang berpengaruh meningkatkan stimulasi simpatis jantung dan peningkatan pada kontraktilitas jantung dalam mendorong darah kembali ke jantung sehingga terjadi peningkatan curah jantung dan tekanan dalam memompa (Sukawati dkk., 2017).

Menurut Mangiwa dkk. (2017), yang mengatakan apabila melakukan gerakan kaki terjadi pergerakan tungkai yang mengakibatkan menegangnya otot-otot tungkai dan menekan vena di sekitar otot tersebut. Hal ini mendorong darah ke arah jantung dan tekanan vena akan menurun, mekanisme ini dikenal dengan pompa vena. Mekanisme ini membantu memperlancarkan peredaran darah bagian kaki dan memperbaiki sirkulasi darah.

Selain itu, gerakan kaki post operasi berfungsi untuk melancarkan sirkulasi darah ke daerah kaki, meningkatkan aliran darah ke ekstremitas bawah dan berperan serta meningkatkan tekanan sistolik pada kaki. Dengan latihan dapat mengurangi efek blokade motorik pada ekstremitas bawah, mengurangi terjadinya kejadian penyakit kardiovaskular dan vena statis pada pembuluh darah kaki. Ada perbedaan MAP sebelum dan sesudah Deep Breathing dengan $\mathrm{p}=0,004$. Hal ini karena inspirasi yang dalam, dapat mendapatkan oksigen yang cukup kemudian saat ekspirasi pasokan oksigen akan menuju ke darah yang kekurangan oksigen (iskemik).

Pada saat itu, terjadi peningkatan sirkulasi darah dan mendorong darah menuuju ke jantung. Menurut penelitian, mengenai latihan nafas dalam dapat memberikan pengaruh terhadap sensitivitas barorefleks. Hasil setelah diberikan intervensi selama seminggu terdapat peningkatan tekanan darah sistolik dari $80 \mathrm{mmHg}$ menjadi $100 \mathrm{mmHg}$ (Damayanti, 2013). Sejalan dengan Triyadi, dkk, (2015), bahwa relaksasi napas dalam berupa menahan inspirasi maksimal dan ekspirasi secara perlahan. Teknik ini berdampak pada fisiologis tubuh yaitu meningkatkan ventilasi paru dan oksigenasi darah. Teknik Deep Breathing melibatkan otot rangka dan otot pernapasan. Saat seseorang inspirasi maksimal, oksigen masuk ke dalam saluran pernapasan dalam jumlah yang cukup. Oksigen akan masuk ke tubuh melalui fase ventilasi, perfusi, difusi hingga transportasi ke pembuluh darah. Dengan rileksnya otot skeleton pada saat ekspirasi, maka terjadi peningkatan prostaglandin kemudian terjadi vasodilatasi pembuluh darah sehingga meningkatkan sirkulasi darah ke daerah yang mengalami iskemik.

Hasil penelitian ini, menunjukkan peningkatan rata-rata MAP pada kelompok kombinasi Leg Exercise dan Deep Breathing yaitu mean post 97,24, mean pre 80,39, mean selisih MAP 16,85 dengan $\mathrm{p}=0,000$. Hasil uji analisis menunjukkan ada perbedaan sebelum dan 
sesudah perlakuan dengan $\mathrm{p}<0,05$. Pada kelompok kombinasi Leg Exercise dan Deep Breathing lebih efektif terhadap peningkatan rata-rata MAP dengan $\mathrm{p}<0,05$. Terdapat peningkatan rata-rata pada kelompok Kontrol dan Leg Exercise bernilai sama dengan p >0,05. Namun pada kelompok Kombinasi lebih tinggi dari Leg Exercise dengan p<0,05. Hasil penelitian ini sejalan dengan Rifai dkk. (2015) mengenai pengaruh mobilisasi dini terhadap perubahan tanda-tanda vital dengan rata-rata MAP sebelum perlakuan 96,99 mmhg dan sesudah perlakuan 103,77 mmhg dengan $\mathrm{p}=0,001$ yang mengatakan mobilisasi dini mempunyai manfaat pada sistem kardiovaskuler dapat meningkatkan curah jantung, memperbaiki kontraksi miokardial, menguatkan otot jantung, memperbaiki aliran balik vena akibat adanya aktivitas fisik yang memicu kaki sehingga mendorong darah menuju jantung. Pada hasil penelitian ini, aktivitas fisik yang memicu aliran balik vena yaitu Kombinasi Leg Exercise dan Deep Breathing.

Pada perlakuan ini lebih tepat sasaran pada kondisi hipotensi pasien dalam meningkatkan tekanan darah pasca operasi. Hal ini dikarenakan ketika dilakukan gerakan rotasi dan fleksi pada kaki yang dilanjutkan relaksasi, bekerja secara berirama dalam melancarkan sirkulasi darah yang berfokus pada pengisian darah menuju jantung. Pada saat ekspirasi, pasokan darah menuju daerah iskemik yaitu kaki dan terjadi peningkatan sirkulasi darah pada daerah tersebut. Setelah terpenuhi pasokan darah, kemudian terjadi peningkatan aliran darah puncak dan aliran darah vena yang bekerja sama mendorong darah menuju jantung agar dilakukan kontraksi dengan tekanan yang maksimal hingga darah terdistribusi secara merata ke seluruh tubuh yaitu pada saat aktif melakukan gerakan kaki dan saat kaki diposisikan $30^{\circ}$. Oleh karena itu, dua teknik ini merupakan siklus yang berkesinambungan dalam mengatasi hipotensi dan masalah trombosis vena dalam akibat blokade saraf simpatis pada anestesi spinal.

\section{SIMPULAN DAN SARAN \\ Simpulan}

Ada perbedaan Mean Arterial Pressure pada ketiga kelompok dengan $p=0,000$. Kombinasi Leg Exercise dan Deep Breathing lebih efektif meningkatkan Mean Arterial Pressure dengan $p=0,000$.

\section{Saran}

Rumah Sakit dapat menerapkan kombinasi leg exercise dan deep breathing sesuai dengan SOP.

\section{UCAPAN TERIMA KASIH}

Peneliti mengucapkan terima kasih kepada pihak-pihak yang telah bekerjasama dan membantu terselesainya karya ilmiah ini. Utamanya pada institusi Poltekkes Semarang dan rumah sakit Roemani Semarang yang telah membantu peneliti.

\section{REFERENSI}

Damayanti, P. (2013). Analisis Praktik Klinik Keperawatan Kesehatan Masyarakat Perkotaan Pada Pasien Gagal Jantung Kongestif. Universitas Indonesia.

Heindel P, A, T., PC, H., MH, P., A, D., NN, P., ... JC, W. (2017). Reoperation rates after single-level lumbar discectomy. PubMed, 42(8).

Kobayashi, K., Ando, K., Nishida, Y., Ishiguro, N., \& Imagama, S. (2018). 
Epidemiological trends in spine surgery over 10 years in a multicenter database. European Spine Journal, 27(8).

Kwon, O.-Y., Jung, D.-Y., Kim, Y., Cho, S.-H., \& Yi, C.-H. (2013). Effects of ankle exercise combined with deep breathing on blood flow velocity in the femoral vein. Australian Journal of Physiotherapy, 49(4).

Luu, B. L., \& Fitzpatrick, R. C. (2013). Blood pressure and the contractility of a human leg muscle. Journal of Physiology, 591(21).

Mangiwa, I., Katuk, M. E., \& Sumarauw, L. (2017). Pengaruh senam kaki terhadap diabetes terhadap nilai ankle brachial index pada pasien diabetes mellitus. Ejournal Keperawatan $(e-K p), 5(1)$.

Ningrum, T. P., Mediani, H. S., \& H.P, C. I. (2017). Faktor-faktor yang berhubungan dengan kejadian wound dehiscence pada pasien post laparotomi. Jurnal Keperawatan Padjajaran, 5(2).

Rifai, A., Hadisaputro, S., \& Supriyadi. (2015). Pengaruh Mobilisasi Dini terhadap Perubahan Tanda-tanda Vital pada Pasien Infark Miokard Akut. Jurnal Ilmu Kesehatan, 11(1).

Riyanto, R., Sutiyono, D., \& Pujo, J. L. (2013). Priapismus Intraoperatif pada Hemoroidektomi dan URS dengan Anestesi Spinal. Jurnal Anestesi, 5(2).

Sihombing, N., Saptarini, I., \& Putri, D. S. K. (2017). Determinan persalinan sectio caesarea di Indonesia (analisis lanjut data Riskesdas 2013). Jurnal Kesehatan Reproduksi, 8(1).

Sjamsuhidajat. (2010). Buku ajar ilmu bedah (3rd ed.). Jakarta: EGC.

Sukawati, D. A., Hartoyo, M., \& Nurullita, U. (2017). Pengaruh Leg Exercise Terhadap Perubahan Tekanan Darah Pasien Post Operasi Laparotomi Dengan Anestesi Umum Di Rsud Dr. H. Soewondo Kendal. E-Journal Stikes Telogorejo, 1(1).

Tanambel, P., Kumaat, L., \& Lalenoh, D. (2017). Profil Penurunan Tekanan Darah ( hipotensi ) pada Pasien Sectio Caesarea yang Diberikan Anestesi Spinal dengan Menggunakan Bupivakain. Jurnal E-Clinic (ECI), 5(1).

The Royal College of Anaesthetists. (2014). Your spinal anaesthetic (4th ed.). United Kingdom: The Association of Anaesthetists of Great Britain and Ireland.

Triyadi, A., Aini, K., \& Ramadhy, A. S. (2015). Pengaruh deep breathing terhadap kecemasan praoperasi pasien di RSUD 45 Kuningan. Jurnal Keperawatan Soedirman (The Soedirman Journal of Nursing), 10(2). 